\title{
Clinical, laboratory and ultrasonographic findings in 87 cows with type-4 abomasal ulcer
}

\author{
Ueli Braun $^{1 *} \mathbb{D}$, Christina Reif ${ }^{1}$, Karl Nuss ${ }^{1}$, Monika Hilbe $^{2}$ and Christian Gerspach ${ }^{1}$
}

\begin{abstract}
Background: This study evaluated the clinical, laboratory, ultrasonographic and pathological findings in 87 cows aged 2 to 10 years ( $4.5 \pm 1.5$ years) with type- 4 abomasal ulcer.

Results: The most common clinical findings were in decreasing order compromised health status accompanied by partial or complete anorexia (100\%), abdominal guarding (81\%), congested scleral vessels (77\%), ruminal atony (73\%), tachycardia (68\%), tachypnoea (65\%), positive foreign body tests $(58 \%)$, decreased skin surface temperature (53\%), fever (49\%), reduction in negative intraabdominal pressure assessed transrectally (39\%), poorly subdivided plant fragments in faeces (35\%) and arched back (28\%). The principal haematological abnormalities were hypokalaemia (72\%), haemoconcentration (69\%), azotaemia (56\%), metabolic acidosis (49\%), hyperfibrinogenaemia (45\%), leukopenia (35\%) and hypoproteinaemia (29\%). Other abnormalities were aciduria (56\%), haematuria (44\%), increased chloride concentration in rumen fluid (34\%) and abnormal peritoneal fluid (98\%). Of 75 examined cows, 65 (87\%) had ultrasonographic evidence of local or generalised peritonitis. On postmortem examination all cows had a type-4 abomasal ulcer and generalised peritonitis. In addition, 36 cows had type-1 ulcers, 6 had type-2 ulcers and one cow had a type-3 ulcer.
\end{abstract}

Discussion: The clinical signs in cows with type-4 abomasal ulcer are associated with generalised peritonitis. An increased haematocrit, indicating shock-induced haemoconcentration is characteristic in contrast to cows with traumatic reticuloperitonitis. Ultrasonography is useful for visualising and assessing generalised peritonitis.

Conclusions: The diagnosis of type-4 abomasal ulcer based on clinical signs alone is difficult and therefore requires additional diagnostic procedures including the determination of the haematocrit and plasma protein concentration, abdominal ultrasonography and analysis of peritoneal fluid. In most cases, these steps lead to a correct diagnosis and allow timely euthanasia of the cow to prevent further suffering and unnecessary treatment costs.

Methods: The cows underwent a clinical, laboratory, ultrasonographic and postmortem examination.

Keywords: Cattle, Abomasum, Type-4 ulcer, Perforated abomasal ulcer, Peritonitis

\section{Background}

Abomasal ulcer disease is of great importance in cattle. Abomasal lesions are divided into erosions and ulcers [1]; erosions are superficial lesions of the mucous membrane and ulcers are deep defects that penetrate the basement membrane of the abomasal mucosa [2]. Abomasal ulcers vary in number and size and can heal

\footnotetext{
* Correspondence: ubraun@vetclinics.uzh.ch

'Department of Farm Animals, Vetsuisse-Faculty, University of Zurich,

Winterthurerstrasse 260, CH-8057 Zurich, Switzerland

Full list of author information is available at the end of the article
}

spontaneously, but this is associated with the formation of a permanent scar [1]. Abomasal ulcers were previously divided into four types [1,3], but a new system that has been used for a number of years classifies ulcers into five types [4]. Classification is based on the depth of penetration, the degree of haemorrhage and the degree of peritonitis caused by the ulcer. Type 1 denotes erosions and/or non-perforated ulcers with minimal haemorrhage; type 2 is associated with severe intraluminal haemorrhage because of erosion of a large blood vessel; type 3 is a perforated ulcer located close to neighbouring

(c) The Author(s). 2019 Open Access This article is distributed under the terms of the Creative Commons Attribution 4.0 International License (http://creativecommons.org/licenses/by/4.0/), which permits unrestricted use, distribution, and 
organs or the peritoneum resulting in acute local peritonitis and adhesions and sometimes the formation of abscesses; and type 4 is a perforated ulcer accompanied by diffuse peritonitis because of contamination of the abdominal cavity with ingesta from the abomasum. Abomasal perforation into the omental bursa associated with localised omental bursitis was previously considered a subset of type-3 ulcer [5] but has since been designated type 5 [4]. Individual cows may have multiple ulcers from more than one classification [2].

The clinical signs vary widely depending on the type of abomasal ulcer; generalised peritonitis is common in cows with type- 4 ulcer and is often fatal within 24 to $48 \mathrm{~h}$ [3]. The clinical signs in cows with type- 4 ulcer resemble those of septic shock and include tachycardia, tachypnoea, fever, congested scleral vessels, pale and muddy mucous membranes, decreased skin surface temperature, spontaneous grunting and abdominal guarding [6, 7]. Abdominal pain was observed in five of seven (71\%) [1] and ten of 22 cows (45\%) with a perforated ulcer [6], respectively. Transrectal palpation reveals absence of or a reduction in the normally negative intraabdominal pressure and the serosal surfaces may have a sandpaper-like texture. Almost all cows have diarrhoea $[6,7]$. Increased haematocrit $(>$ $35 \%)$ accompanied by a decrease in total protein $(<60 \mathrm{~g} / \mathrm{l})$ and leukocytosis attributable to neutrophilia, often with a left shift, are common [6, 7]. Metabolic acidosis has also been reported in cows with type- 4 abomasal ulcer [7].

Ultrasound examination can be helpful in assessing the position, size, wall and content of the abomasum and possible inflammatory lesions that involve neighbouring organs [8]. However, mucosal erosions and type-1 ulcers that were diagnosed at postmortem in 16 of $50(32 \%)$ clinically healthy cows were missed ultrasonographically [9]. When blood is aspirated during abomasocentesis, the likelihood of abomasal ulcer is high [10]. Ultrasonography was identified as the most important diagnostic procedure in a cow with abomasal lymphosarcoma [11]; a thickened abomasal wall and prominent abomasal leaves accompanied by enlarged lymph nodes were considered diagnostic. Ultrasonographic findings in cows with peritonitis vary widely [8]. Fibrinous peritonitis is characterised by echogenic deposits on the peritoneum and organ surfaces in the absence of effusion, but fibrin may have fluid inclusions. Anechoic to hypoechoic fluid accumulation (inflammatory ascites) interspersed with fibrin strands between organs may be seen in generalised peritonitis. With a perforated ulcer, ingesta can be seen as an echogenic coating on various abdominal organs.

Because the clinical diagnosis of type- 4 abomasal ulcer is not straightforward, and detailed investigations of large numbers of cows with this ulcer type are lacking, the purpose of this study was to describe the clinical, laboratory and ultrasonographic findings of cows with type- 4 abomasal ulcer to facilitate the diagnosis of this disease.

\section{Methods \\ Animals}

This was a retrospective study of 87 cows that had a main diagnosis of type- 4 abomasal ulcer. The cows had been admitted to the Veterinary Teaching Hospital, University of Zurich, from January 1, 1991 to December 31, 2014. The final diagnosis was based on the results of postmortem examination. The results were described in detail [12]. The cows ranged in age from 2 to 10 years (mean \pm standard deviation [sd], $4.5 \pm 1.5$ years). Breeds included Brown Swiss (36), Holstein-Friesian (25), Swiss Fleckvieh (24) and crossbred cattle (2). The duration of illness was $<2$ days in 36 cows, 2 to 6 days in 40 cows, 7 to 14 days in 6 cows and $>14$ days in 4 cows. The majority of cows $(n=36,49 \%)$ became ill within 4 weeks after calving (Fig. 1); this incidence was significantly higher than that of other stages of lactation $(P<0.01)$. Twenty-four cows had been treated with non-steroidal anti-inflammatory drugs (NSAIDs), six with corticosteroids and another six with NSAIDs and corticosteroids before referral, but the exact dosages were not known.

\section{Clinical examination}

The cows underwent a thorough clinical examination [13]. General health was evaluated by determining demeanour, appearance of hair coat and muzzle, skin elasticity, position of the eyes in the sockets and skin surface temperature. Each cow was observed for signs of pain such as spontaneous grunting and bruxism. The rumen was assessed for degree of fill, number and intensity of contractions and content stratification. Sensitivity in the reticular region was assessed by preventing the animal from breathing for a short period by placing a plastic rectal sleeve over the mouth and nose and listening for grunting during the ensuing deep breath. This was followed by foreign body tests, which included the pole test, back grip and percussion of the abdominal wall over the region of the reticulum with a rubber hammer. Each test was carried out 4 times as described [14], and the reaction of the animal was observed each time. A test was considered positive when it elicited a short grunt at least three out of four times. The response to a test was considered questionable when it elicited a grunt two out of four times and negative when the animal did not grunt or grunted only once. Ballottement and simultaneous auscultation as well as percussion and simultaneous auscultation of the abdomen on both sides and rectal examination were also carried out. Faeces were assessed for colour, consistency, amount, fibre particle length and abnormal contents. 


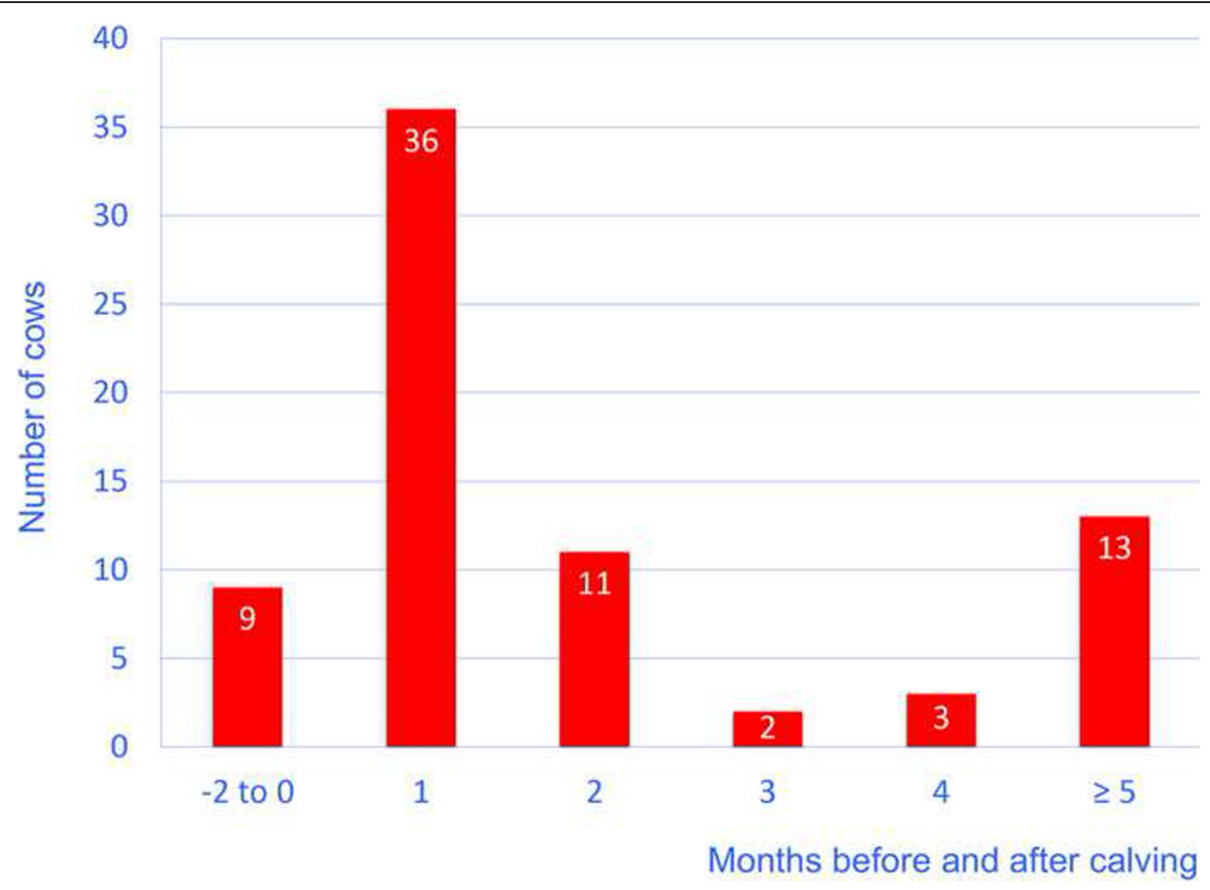

Fig. 1 Frequency of type-4 abomasal ulcers in 87 cows during the lactation cycle

\section{Laboratory analyses}

The following blood samples were collected from all cows: $5 \mathrm{ml}$ of EDTA blood for haematological analysis, $10 \mathrm{ml}$ of whole blood for serum biochemistry, $2 \mathrm{ml}$ of whole blood mixed with $0.2 \mathrm{ml}$ heparin for venous blood gas analysis and $5 \mathrm{ml}$ of EDTA blood for the glutaraldehyde test. Haematological analysis included the determination of haematocrit, total leukocyte count and the concentrations of fibrinogen and total protein using an automated blood analyser (CELL-Dyn 3500, Abbott Diagnostics Division, Baar). The concentration of serum urea nitrogen was determined at $37{ }^{\circ} \mathrm{C}$ using an automated analyser (Cobas-Integra-800-Analyser, Roche Diagnostics, Basel) and the manufacturer's reagents (Roche Reagents) according to the International Federation of Clinical Chemistry and Laboratory Medicine (IFCC). Venous blood gas analysis was done using an automated analyser (RapidLab 248, Siemens Schweiz AG, Zurich). A glutaraldehyde test (Glutaltest ${ }^{\oplus}$, Graeub AG, Bern) was done according to the manufacturer's instructions. Results were interpreted relative to reference intervals recently reported [15].

A urine sample, mainly collected during spontaneous micturition, was analysed in 76 cows. The colour and transparency of the urine were assessed macroscopically, and the specific gravity was determined using a refractometer (HRMT 18, A. Krüss Optronic GmbH, Hamburg, Germany). A urine test strip (Combur9 ${ }^{\circledR}$, Roche, Basel) was used to determine $\mathrm{pH}$ and the presence of protein, erythrocytes, glucose, ketones, leukocytes, nitrite, urobilinogen and bilirubin.

A sample of rumen fluid (200 to $300 \mathrm{ml}$ ) was collected using a Dirksen probe [13] in 67 cows and assessed for colour, odour, consistency and $\mathrm{pH}$. In addition, the methylene blue reduction time and the concentration of chloride were determined. The concentration of chloride in rumen fluid was carried out using an MK-II-Chloride Analyser 9265 (Sherwood, Cambridge).

\section{Ultrasonographic examination and abdominocentesis}

Seventy-five cows underwent ultrasonographic examination of the reticulum $(n=58)$, abomasum $(n=21)$ and abdomen $(n=63)$ using a 3.5 or $5.0 \mathrm{MHz}$ convex or linear transducer [16]. Echogenic deposits, with or without hypoechoic or anechoic fluid inclusions, and structures of various shapes and echogenicities with central echogenic fluid collections, reflect inflammatory changes of the peritoneum that include fibrinous deposits and abscesses were interpreted and referred to as inflammatory lesions of the peritoneum $[16,17]$.

Amount and appearance of fluid accumulations and fibrin strands were noted. Forty-seven cows with ultrasonographic evidence of abdominal fluid accumulation underwent ultrasound-guided abdominocentesis [18] and the aspirated fluid was assessed macroscopically with respect to colour, odour and transparency. Specific gravity and total solids were measured with a refractometer. The aspirated fluid was considered an exudate 
when at least one of the following criteria was met: specific gravity $>1.015$, total solids $>30 \mathrm{~g} / \mathrm{l}$, cloudy appearance, malodourous appearance and green discolouration.

\section{Euthanasia}

All severely affected cows that did not die spontaneously were euthanased immediately after the initial examination or after 2 to 4 days of unsuccessful treatment. Euthanasia was done with pentobarbital (Esconarkon, Streuli Pharma), $80 \mathrm{mg} / \mathrm{kg}$ body weight intravenously.

\section{Statistical analysis}

The program IBM SPSS Statistics 22.0 was used for analysis. Frequencies were determined for each variable. The Wilk-Shapiro test was used to test the data for normality. Means \pm standard deviations were calculated for normal data (total protein) and medians for non-normal data (heart rate, respiratory rate, rectal temperature, haematocrit, white blood cell count, fibrinogen and urea concentration, glutaraldehyde test coagulation time, $\mathrm{pH}, \mathrm{pCO}_{2}$, $\mathrm{HCO}_{3}{ }^{-}$and base excess of venous blood, urine $\mathrm{pH}$, urine specific gravity). Differences in ulcer occurrence at various stages of lactation were analysed using a one-way analysis of variance and the post hoc Bonferroni test. A value of $P<0.05$ was considered significant.

\section{Results}

Overview of the most common clinical findings

The most common clinical findings in decreasing frequency were compromised health status accompanied by partial or complete anorexia (100\%), abdominal guarding $(81 \%)$, congested scleral vessels $(77 \%)$, ruminal atony $(73 \%)$, tachycardia $(68 \%)$, tachypnoea $(65 \%)$, positive foreign body tests $(58 \%)$, decreased skin surface temperature (53\%), fever (49\%), reduction in negative intraabdominal pressure assessed transrectally (39\%), poorly digested plant fragments in faeces (35\%) and arched back (28\%) (Fig. 2).

\section{Health status, behaviour, posture and signs of pain}

All cows were ill and had reduced appetite or anorexia. Five $(6 \%)$ cows were down at the time of admission, 24 (28\%) were obtunded, 13 (15\%) had muscle tremors and 24 (28\%) had an arched back. Six (7\%) cows had droopy ears and $4(5 \%)$ had a droopy head. Two (2\%) cows had a sawhorse stance and two others had abducted elbows. The principal signs of abdominal pain were bruxism

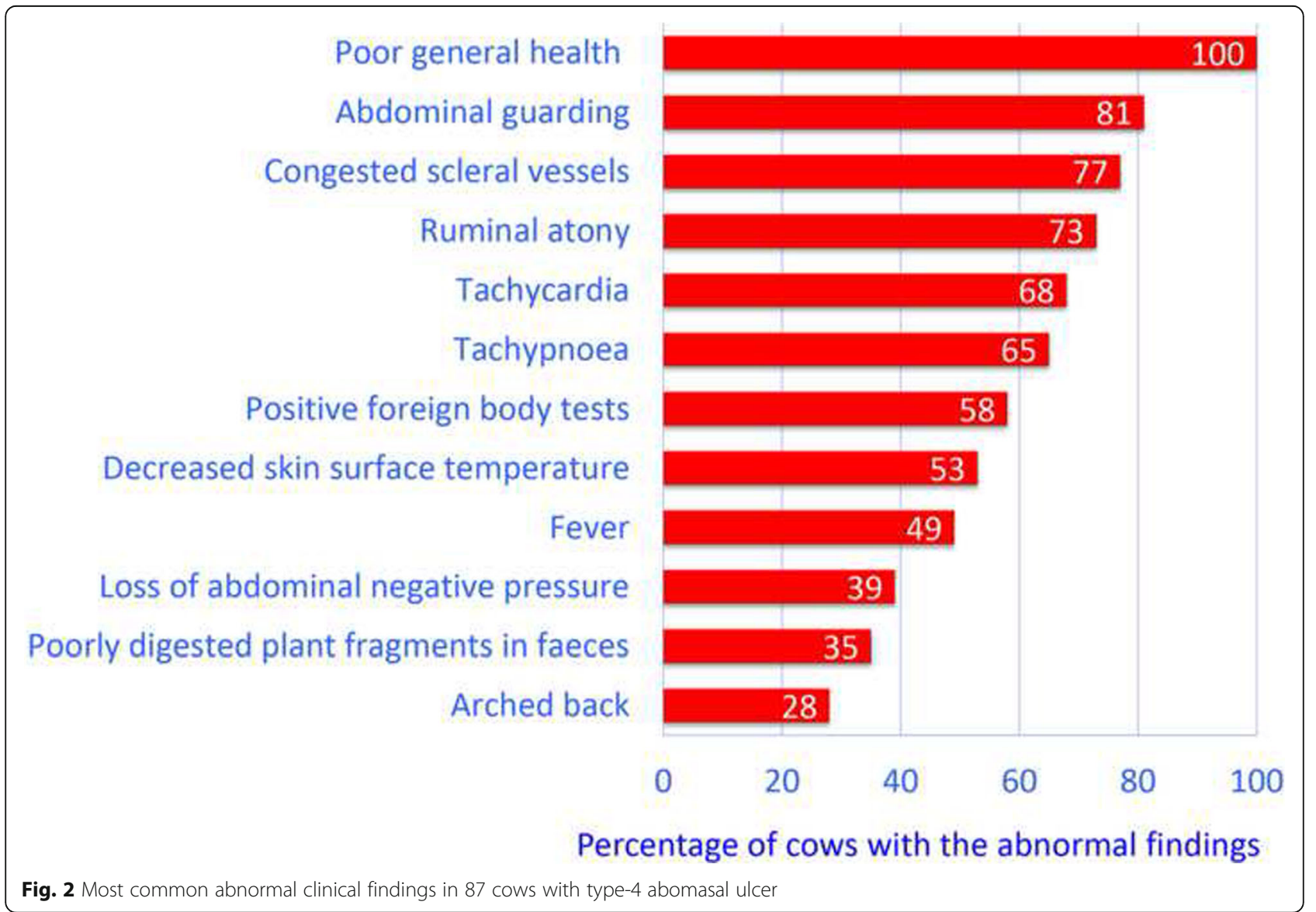


( $n=22,25 \%)$, spontaneous grunting $(n=16,18 \%)$ and colic (restlessness and weight shifting in fore- and hind limbs, sunken back, kicking at the belly; $n=7,8 \%$ ).

\section{Circulatory and respiratory systems and temperature}

The heart rate ranged from 44 to 196 beats/min (median, 98 beats/min) (Table 1) and 59 (68\%) cows had tachycardia. The respiratory rate ranged from 14 to 80 breaths/min (median, 32 breaths/min) and was increased in $56(65 \%)$ cows. The rectal temperature ranged from 36.0 to $40.5^{\circ} \mathrm{C}$ (median, $38.9^{\circ} \mathrm{C}$ ); 24 (28\%) cows had hypothermia and 43 (49\%) had pyrexia. The skin surface temperature was lower than normal in 45 (53\%) cows and warmer than normal in four (5\%). Sixty-six (77\%) cows had congested scleral vessels, 23 (27\%) had pale mucous membranes and six (7\%) cows each had hyperaemic and cyanotic mucous membranes.

\section{Digestive system}

Sixty-eight (81\%) cows had abdominal guarding and six (7\%) had abdominal distension. Rumen motility was reduced in 22 (26\%) cows and absent in 63 (73\%) (Table 1). Of the 76 cows that underwent foreign body testing, 35 (46\%) reacted to the pole test, $31(41 \%)$ to the back grip and $25(33 \%)$ to percussion of the reticular area. Twelve (16\%) cows had one positive test, 18 (24\%) cows had two and in 14 (18\%), all three tests were positive. In 32 (42\%) cows, all three tests were negative or equivocal and 44 (58\%) cows had at least one positive test. Swinging and/ or percussion and auscultation was positive in 13 (15\%) cows on the left and in $44(51 \%)$ on the right. Fifty-five (63\%) cows had abnormal transrectal palpation findings; 34 (39\%) had partial or complete loss of negative abdominal pressure and 9 (10\%) cows had serosal surfaces with a sandpaper-like texture. The rumen was dilated in 14 cows and gaseous distension of the small intestines was diagnosed in five cows. Eight cows had miscellaneous abnormal rectal findings including caecal dilatation and right displacement of the abomasum characterised by a gas-filled area of the abomasum. Faecal output was reduced in $57(66 \%)$ cows and $12(14 \%)$ cows had an empty rectum. Faecal consistency varied widely from loose to firm and only 14 (19\%) cows had diarrhoea and passed thin semifluid to watery faeces. The colour of the faeces was dark to black in $12(16 \%)$ cows and the degree of comminution was moderate to poor in 26 (35\%) cows.

\section{Laboratory findings (blood, urine, rumen fluid)}

The most important abnormal blood variables in decreasing frequency were hypokalaemia (72\%), haemoconcentration (69\%), azotaemia (56\%), metabolic acidosis (49\%), hyperfibrinogenaemia (45\%), leukopenia (35\%) and hypoproteinaemia (29\%) (Fig. 3). The haematocrit was decreased
(11 to $29 \%$ ) in 11 (13\%) cows and increased (36 to $62 \%$ ) in 60 (69\%) cows (Table 2). Leukocyte numbers ranged from 1600 to $24,600 / \mu$ blood; 30 (35\%) cows had leukopenia (< 5000 leukocytes/ $\mu \mathrm{l}$ blood) and 16 (19\%) cows had leukocytosis ( $>10,000$ leukocytes/ $\mu$ l blood). Total protein concentration was decreased (40 to $59 \mathrm{~g} / \mathrm{l}$ ) in 25 (29\%) cows and increased ( 81 to $93 \mathrm{~g} / \mathrm{l}$ ) in 10 (11\%) cows). Seventeen (20\%) cows had hypoproteinaemia ( $<60 \mathrm{~g}$ total protein/l) combined with haemoconcentration (haematocrit $>35 \%$ ). Hyperfibrinogenaemia (8 to $13 \mathrm{~g} / \mathrm{l}$ ) occurred in 39 (45\%) cows. Forty-eight (56\%) cows had azotaemia (blood urea nitrogen $>6.6 \mathrm{mmol} / \mathrm{l})$. The glutaraldehyde coagulation test time was shortened $(<10 \mathrm{~min})$ in $17(22 \%)$ cows and prolonged (16 to $60 \mathrm{~min}$ ) in 7 (9\%) cows. Venous blood gas analysis showed a decreased $\mathrm{pH}(<7.4)$ in $35(49 \%)$ cows and an increased $\mathrm{pH}$ in 18 (25\%) cows.

Urinalysis showed aciduria $(\mathrm{pH}<6.5)$ in $35(56 \%)$ cows and haematuria (5 to 250 erythrocytes per high-power field) in 33 (44\%) cows with macroscopically normal urine (Fig. 4). Six (8\%) cows had proteinuria ( 1 to $1.5 \mathrm{~g} / \mathrm{l}), 8$ (11\%) had ketonuria ( 0.1 to $1.5 \mathrm{~g} /$ l) and $18(24 \%)$ had glucosuria (0.5 to $10.0 \mathrm{~g} / \mathrm{l}$ ) (not shown in Fig. 4). The chloride concentration in rumen fluid was increased (> $25 \mathrm{mmol} / \mathrm{l})$ in 23 (34\%) cows. The sample of aspirated peritoneal fluid was an exudate in 46 (98\%) of 47 cows and normal in the remaining cow; 39 samples were yellow, 5 were haemorrhagic and the remaining 2 were green. Twenty-two samples were opaque and 3 were malodorous. The specific gravity varied from 1.013 to 1.045 (mean $\pm \mathrm{sd}$, $1.029 \pm 8.6)$ and the protein concentration from 4 to $76 \mathrm{~g} / \mathrm{l}$ (median, $36.4 \mathrm{~g} / \mathrm{l}$ ).

\section{Ultrasonographic findings}

The reticulum was raised from the ventral abdominal wall in 20 cows, had an abnormal contour in 19 cows and decreased amplitude of contraction in 12 cows (Table 3). Reticular atony was diagnosed in 36 cows, echogenic changes with or without fluid inclusions in 40 cows and free fluid in the reticular area in seven cows (Figs. 5 and 6). Other findings were abomasal dilatation in five cows, left displacement of the abomasum in three and right displacement of the abomasum in four cows. Fourteen cows had fibrinous changes and/or free abdominal fluid associated with the abomasum. When an ulcer was accompanied by left displacement of the abomasum, massive inflammatory changes were also seen adjacent to the left abdominal wall (Figs. 7 and 8). Generalised echogenic changes (Fig. 9) were seen in 36 cows and generalised fluid accumulations in seven cows. Overall, 65 (87\%) of the 75 scanned cows had ultrasonographic evidence of local or generalised peritonitis. 
Table 1 Clinical findings in cows with type-4 abomasal ulcer

\begin{tabular}{|c|c|c|c|}
\hline Variable & Finding & Number of cattle & $\%$ \\
\hline \multirow{5}{*}{$\begin{array}{l}\text { Heart rate }(n=87, \text { median }=98 \\
\text { bpm) }\end{array}$} & Normal (60-80) & 26 & 30 \\
\hline & Decreased (44-59) & 2 & 2 \\
\hline & Mildly increased (81-100) & 23 & 26 \\
\hline & Moderately increased (101-120) & 23 & 26 \\
\hline & Severely increased (121-196) & 13 & 15 \\
\hline Respiratory rate & Normal (15-25) & 28 & 33 \\
\hline \multirow[t]{4}{*}{$(n=86$, median $=32$ breaths per min. $)$} & Decreased (14) & 2 & 2 \\
\hline & Mildly increased (26-35) & 23 & 27 \\
\hline & Moderately increased (36-45) & 16 & 18 \\
\hline & Severely increased (46-80) & 17 & 2 \\
\hline \multirow{5}{*}{$\begin{array}{l}\text { Rectal temperature } \\
(n=87, \text { median }= \\
\left.38.9^{\circ} \mathrm{C}\right)\end{array}$} & Normal (38.4-38.9) & 20 & 23 \\
\hline & Decreased (36.0-38.3) & 24 & 28 \\
\hline & Mildly increased (39.0-39.4) & 17 & \\
\hline & Moderately increased (39.5-40.0) & 23 & \\
\hline & Severely increased (40.1-40.5) & 3 & 3 \\
\hline \multirow{3}{*}{$\begin{array}{l}\text { Rumen motility } \\
(n=86)\end{array}$} & Normal & 1 & 1 \\
\hline & Decreased & 22 & 26 \\
\hline & Absent & 63 & 73 \\
\hline \multirow{7}{*}{$\begin{array}{l}\text { Foreign body tests } \\
(n=76)\end{array}$} & All negative & 32 & 42 \\
\hline & Pole test positive ${ }^{1}$ & 35 & 46 \\
\hline & Back grip positive ${ }^{1}$ & 31 & 41 \\
\hline & Percussion of the reticular region positive ${ }^{1}$ & 25 & 33 \\
\hline & 1 of 3 tests positive & 12 & 16 \\
\hline & 2 of 3 tests positive & 18 & \\
\hline & 3 of 3 tests (all tests) positive & 14 & 18 \\
\hline \multirow{4}{*}{$\begin{array}{l}\text { Swinging and per-cussion auscultation } \\
\text { on the left side } \\
(\mathrm{n}=87)\end{array}$} & Both negative (normal) & 74 & 85 \\
\hline & Only swinging auscultation positive & 3 & 3 \\
\hline & Only percussion auscultation positive & 4 & 5 \\
\hline & Both tests positive & 6 & 7 \\
\hline \multirow{4}{*}{$\begin{array}{l}\text { Swinging and per-cussion auscultation } \\
\text { on the right side } \\
(n=87)\end{array}$} & Both negative (normal) & 43 & 49 \\
\hline & Only swinging auscultation positive & 17 & 20 \\
\hline & Only percussion auscultation positive & 9 & 10 \\
\hline & Both tests positive & 18 & 21 \\
\hline \multirow{8}{*}{$\begin{array}{l}\text { Rectal findings } \\
(n=87)\end{array}$} & Normal findings & 44 & 51 \\
\hline & Loss of negative pressure & 34 & 39 \\
\hline & Sandpaper-like texture of serosa & 9 & 10 \\
\hline & Rumen dilated & 14 & 16 \\
\hline & Gaseous distension of the small intestines & 5 & 6 \\
\hline & Miscellaneous abnormal findings & 8 & 9 \\
\hline & Faecal output reduced & 57 & 66 \\
\hline & Empty rectum & 12 & 14 \\
\hline
\end{tabular}

${ }^{1}$ Positive: at least 3 of 4 attempts elicited a grunt 


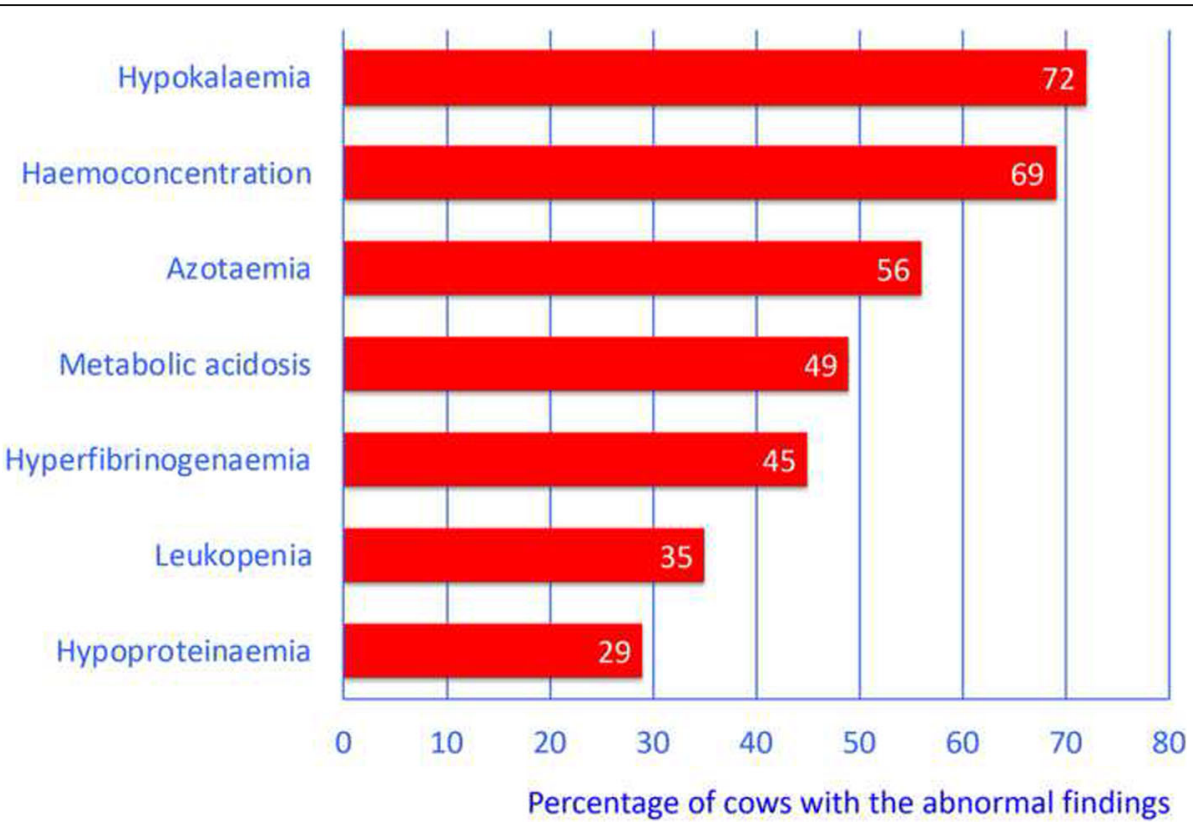

Fig. 3 Most common abnormal blood variables in 87 cows with type-4 abomasal ulcer

Table 2 Haematological and blood biochemical findings in cows with type-4 abomasal ulcer

\begin{tabular}{|c|c|c|c|}
\hline Variable (mean \pm sd or median) & Finding & Number of cattle & Percent \\
\hline \multirow{3}{*}{$\begin{array}{l}\text { Haematocrit (\%) }(n=87 \\
\text { median, } 40 \%)\end{array}$} & Normal (30-35) & 16 & 18 \\
\hline & Decreased (11-29) & 11 & 13 \\
\hline & Increased (36-62) & 60 & 69 \\
\hline \multirow{3}{*}{$\begin{array}{l}\text { White blood cell count }(/ \mu \mathrm{l}) \\
(n=86 ; \text { median, } 6300 / \mu \mathrm{l})\end{array}$} & Normal $(5000-10,000)$ & 40 & 46 \\
\hline & Decreased (1600 - 4999) & 30 & 35 \\
\hline & Increased $(10,001-24,600)$ & 16 & 19 \\
\hline \multirow{3}{*}{$\begin{array}{l}\text { Total protein concentration } \\
(n=87 ; \text { mean } \pm \mathrm{sd}, 65.3 \pm \\
12.5 \mathrm{~g} / \mathrm{l})\end{array}$} & Normal (60-80) & 52 & 60 \\
\hline & Decreased (40-59) & 25 & 29 \\
\hline & Increased (81-93) & 10 & 11 \\
\hline \multirow{3}{*}{$\begin{array}{l}\text { Fibrinogen concentration } \\
(n=86 ; \text { median, } 6.0 \mathrm{~g} / \mathrm{l})\end{array}$} & Normal (4-7) & 39 & 45 \\
\hline & Decreased (2-3) & 8 & 10 \\
\hline & Increased (8-13) & 39 & 45 \\
\hline \multirow{2}{*}{$\begin{array}{l}\text { Urea concentration ( } n=86 \text {; } \\
\text { median, } 7.3 \mathrm{mmol} / \mathrm{l})\end{array}$} & Normal (2.4-6.5) & 38 & 44 \\
\hline & Increased (6.6-28.6) & 48 & 56 \\
\hline \multirow{3}{*}{$\begin{array}{l}\text { Potassium concentration }(n=86 ; \\
\text { median, } 3.6 \mathrm{mmol} / \mathrm{l})\end{array}$} & Normal (4.0-5.0) & 17 & 20 \\
\hline & Decreased (1.6-3.9) & 62 & 72 \\
\hline & Increased (5.1-7.5) & 7 & 8 \\
\hline \multirow{3}{*}{$\begin{array}{l}\text { Glutaraldehyde test ( } n=76 \text {; } \\
\text { median, } 10.0 \text { min.) }\end{array}$} & Normal (10-15) & 52 & 69 \\
\hline & Decreased (1.5-9.9) & 17 & 22 \\
\hline & Prolonged (1.5-9.9) & 7 & 9 \\
\hline
\end{tabular}




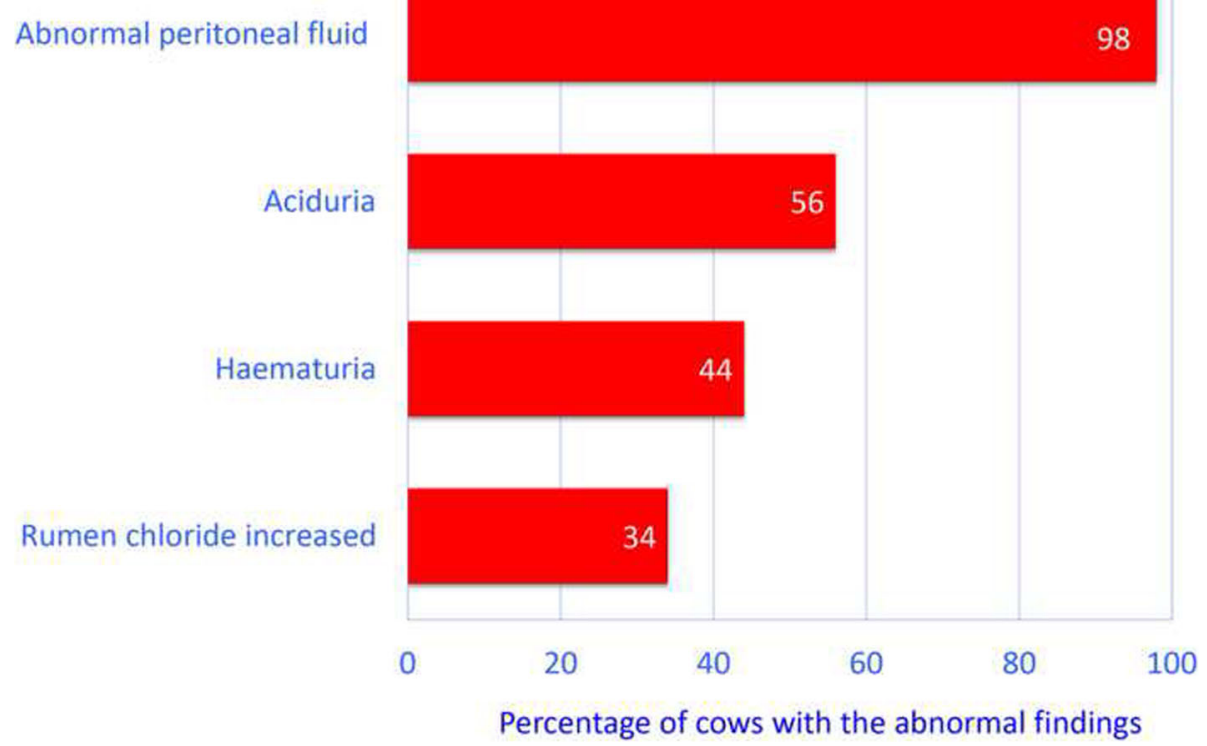

Fig. 4 Most common abnormal findings in peritoneal fluid, urine and rumen fluid from 87 cows with type-4 abomasal ulcer

\section{Concurrent diseases}

Comorbidity occurred in 29 (33\%) cows; 20 cows had one, seven cows had two and two cows had three or more additional diseases. The most common problems were claw disorders $(n=24)$, left or right displacement of the abomasum $(n=7)$, fatty liver syndrome $(n=6)$, metritis or endometritis $(n=6)$, fascioliasis $(n=6)$, mastitis $(n=1)$ and ketosis $(n=1)$.

\section{Diagnosis and treatment attempts}

A tentative diagnosis of type- 4 abomasal ulcer was made in $66(76 \%)$ cows, and in 21 (24\%) cows, the diagnosis was not clear. Fifty-four (62\%) cows in which a type-4 ulcer was diagnosed were euthanased immediately except for a few that died during the examination. Twelve (14\%) cows underwent right flank exploratory laparotomy to confirm the diagnosis and all were euthanased because of generalised peritonitis. The cows with an unclear diagnosis received a continuous intravenous infusion of a sodium-chloride-glucose solution (10 l per day, $9 \mathrm{~g}$ sodium chloride and $50 \mathrm{~g}$ glucose per litre), antibiotics (procaine penicillin G procaine, $12,000 \mathrm{IU} / \mathrm{kg}$ body weight) and an NSAID (flunixin meglumine, $1 \mathrm{mg} / \mathrm{kg}$ ), and two cows also received a magnet. Six cows died after

Table 3 Ultrasonographic findings in cows with type-4 abomasal ulcer

\begin{tabular}{|c|c|c|}
\hline Location & Findings & Number of cows \\
\hline \multirow{6}{*}{$\begin{array}{l}\text { Reticulum } \\
(n=58)\end{array}$} & Elevated from ventral abdominal wall & 20 \\
\hline & Contour abnormal & 19 \\
\hline & Amplitudes of contraction decreased & 12 \\
\hline & Reticular atony & 36 \\
\hline & Echogenic changes with or without fluid inclusions & 40 \\
\hline & Free fluid in reticular region & 7 \\
\hline \multirow{5}{*}{$\begin{array}{l}\text { Abomasum } \\
(n=47)\end{array}$} & Dilated & 5 \\
\hline & Left displacement & 3 \\
\hline & Right displacement & 4 \\
\hline & Fibrin deposits on serosa & 7 \\
\hline & Free fluid in abomasal region & 7 \\
\hline \multirow[t]{2}{*}{ Abdomen } & Generalised echogenic lesions & 36 \\
\hline & Generalised free fluid & 7 \\
\hline
\end{tabular}




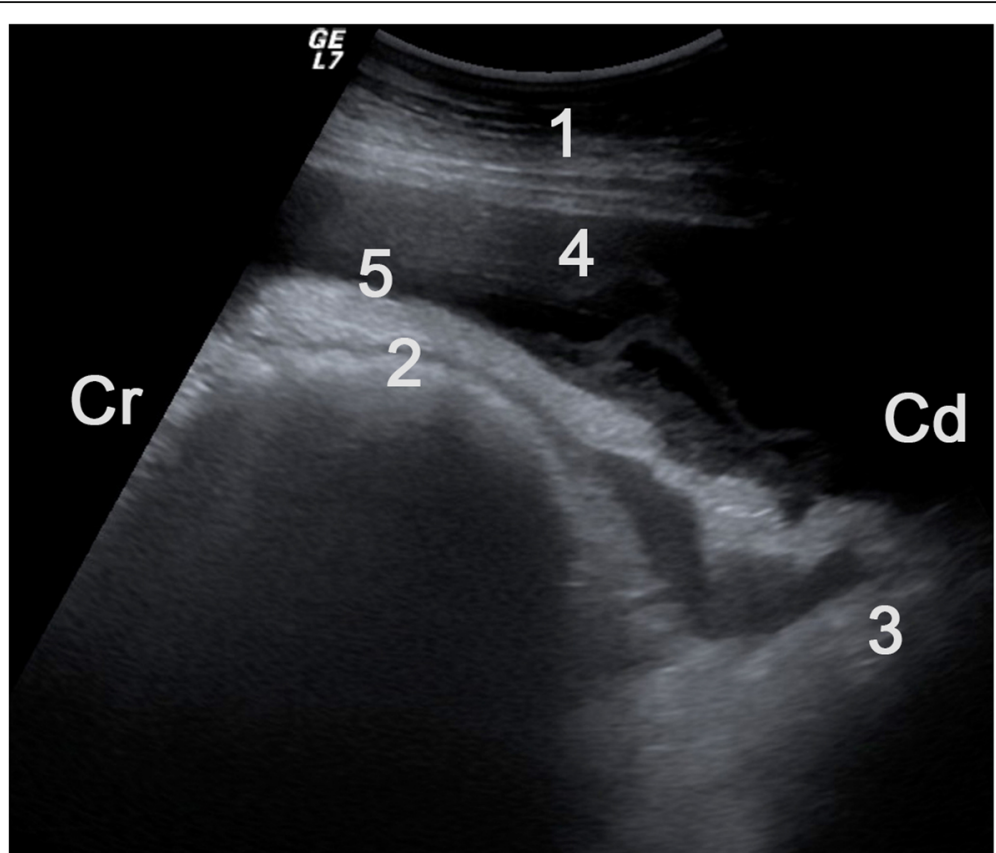

Fig. 5 Ultrasonogram of the reticulum obtained from the ventral abdominal wall showing fibrinous changes and effusion in the reticular area in a 2.6-year-old Holstein-Friesian cow with type-4 abomasal ulcer. A 5.0-MHz convex transducer was used. 1 Ventral abdominal wall, 2 Reticulum, 3 Anterior dorsal blind sac of rumen, 4 Extensive fluid accumulation ventral and caudal to reticulum, 5 Fibrin on the serosal surface of the reticulum extending to dorsal blind sac of rumen, Cr Cranial, Cd Caudal

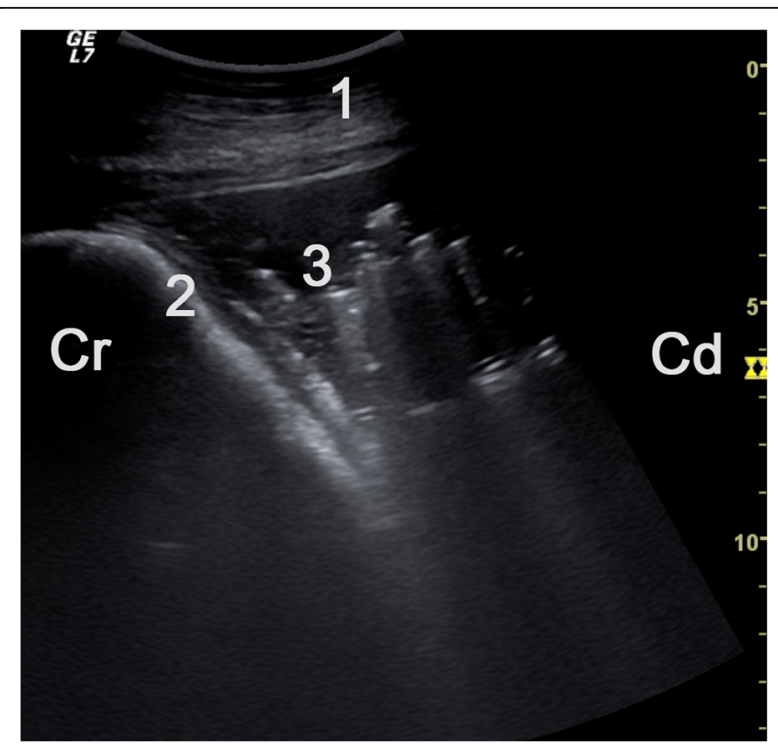

Fig. 6 Ultrasonogram of the reticular area obtained from the ventral abdominal wall showing fluid accumulation with gaseous inclusions in a 3.9-year-old Brown-Swiss cow with type-4 abomasal ulcer. A 5.0$\mathrm{MHz}$ linear transducer was used. The echogenic stippling in the fluid represents gas produced by bacteria. The aspirated peritoneal fluid was opaque and the specific gravity and protein concentration were increased at 1.033 and $50 \mathrm{~g} / \mathrm{l}$, respectively. The fluid contained 225 cells/ $\mu$ and cytological examination of a smear showed many bacteria (which were responsible for gas production). 1 Ventral abdominal wall, 2 Reticulum, 3 Fluid with gaseous inclusions, Cr Cranial, Cd Caudal the start of treatment and the remaining 15 were euthanased after two to four days because of deterioration in condition.

\section{Postmortem diagnosis}

All cows underwent portmortem examination and all had a type- 4 abomasal ulcer and generalised peritonitis (Figs. 10, 11 and 12). Thirty-six cows also had a type-1 ulcer, six cows had a type- 2 ulcer and one cow had a type-3 ulcer.

\section{Discussion}

Forty-nine percent of all cases of type-4 abomasal ulcer occurred during the first four weeks of lactation, which had the highest incidence of all lactational stages. This was in general agreement with other reports $[1,6,19-$ 21]. Stressors affecting cows in the periparturient period, in addition to parturition, include the movement from the dry cow pen to the milking herd $[22,23]$ and the transition to a carbohydrate-rich ration [24], onset of lactation and a variety of typical early-lactation disorders [25]. These stressors are responsible for enhanced secretion of cortisol, hydrochloric acid and pepsin and also result in reduced secretion of prostaglandin $E[25,26]$. Comorbidity was common in the present study and one third of all cows had one or more additional disorders. In an earlier study, 39 of 43 cows with perforated abomasal ulcer had one or more additional disorders [6]. 


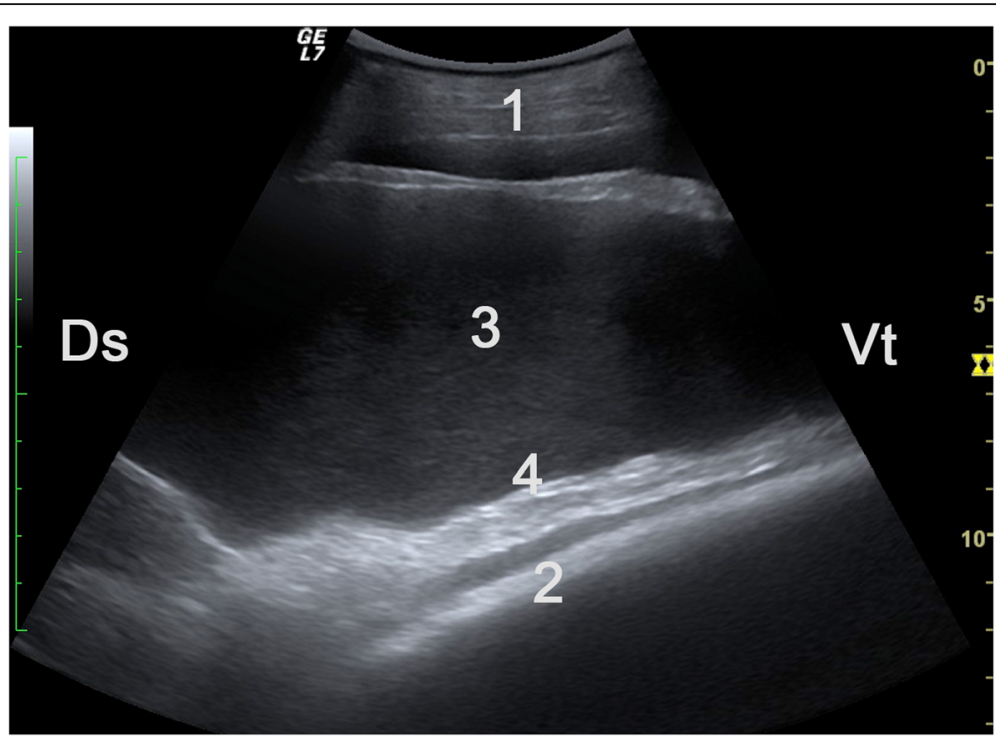

Fig. 7 Ultrasonogram obtained from the left flank showing massive hypoechoic effusion in a 2-year-old Holstein-Friesian cow with type-4 abomasal ulcer and left displacement of the abomasum. A 5.0-MHz convex transducer was used. 1 Abdominal wall in the left flank, 2 Rumen, 3 Massive accumulation of hypoechoic fluid between rumen and left abdominal wall, 4 Thickened greater omentum, Ds Dorsal, Vt Ventral

Advanced pregnancy and early lactation in dairy cows is associated with increased stress, which was evidenced by increased hair cortisol concentrations in periparturient cows $[27,28]$ and in cows three weeks after parturition [27] compared with cows at other reproductive stages. Some of the cows had received NSAIDs and/or corticosteroids before referral; however, we were not able to determine when these drugs were given or the dosages used. It cannot be ruled out that these treatments were involved in the pathogenesis of the ulcers or in the perforation of a pre-existing type-1 or -2 ulcer. Anti-inflammatory drugs such as corticosteroids and salicylic acid have been implicated in the pathogenesis of abomasal ulcer [7] and their use should be limited to 3 days. The clinical signs in cows with type- 4 abomasal ulcer are associated with generalised peritonitis and have been

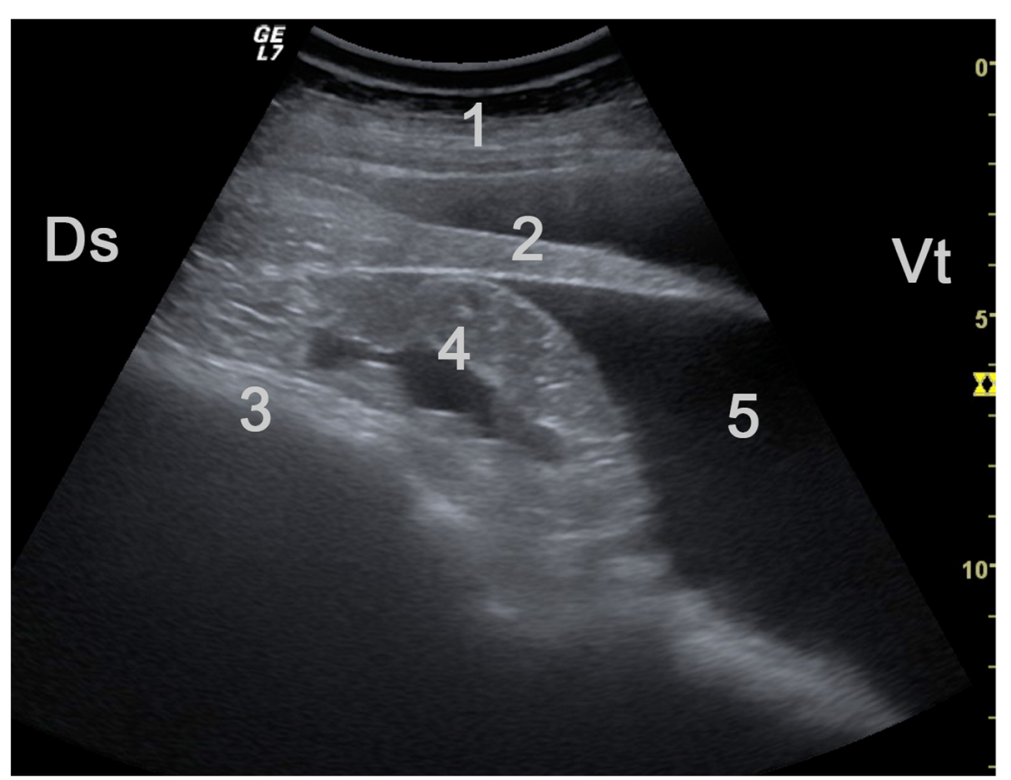

Fig. 8 Ultrasonogram obtained from the left 7th intercostal space of the cow in Fig. 7 showing extensive intraabdominal inflammatory lesions. A 5.0-MHz convex transducer was used. The spleen is surrounded by hypoechoic fluid, and echoic inflammatory changes interspersed with fluid are seen between the spleen and rumen. 1 Lateral abdominal wall, 2 Spleen, 3 Rumen, 4 Echoic inflammatory changes interspersed with fluid, 5 Fluid accumulation, Ds Dorsal, Vt Ventral 


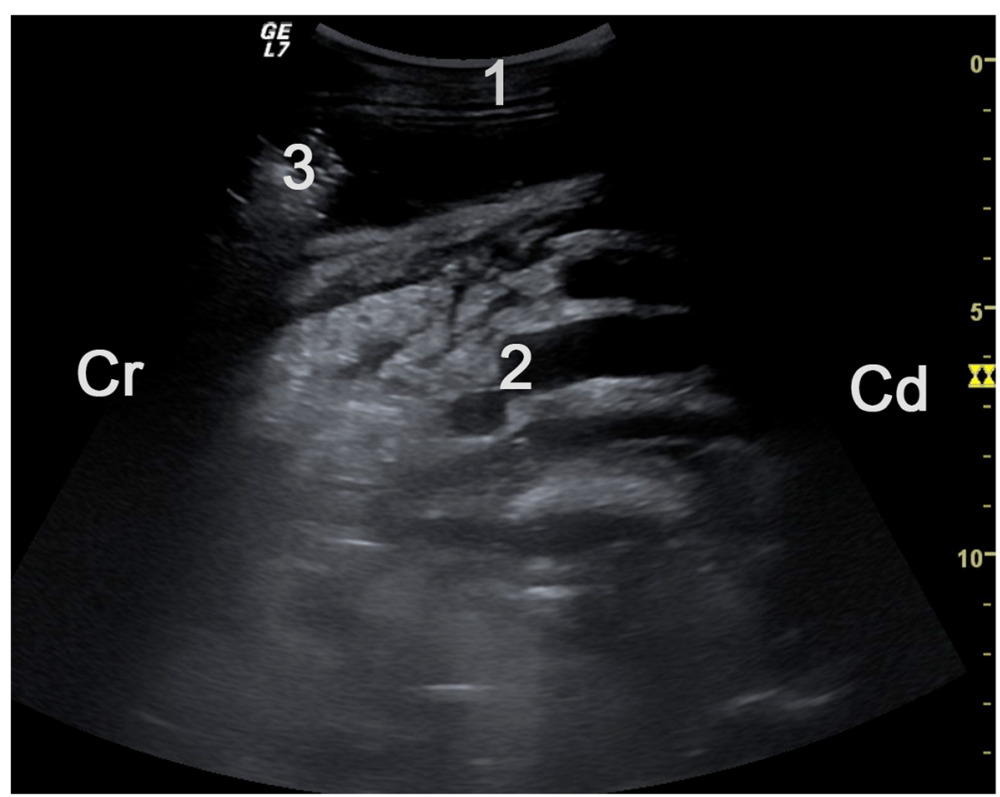

Fig. 9 Ultrasonogram obtained from the right paramedian area caudal to the reticulum of the cow of Fig. 6 showing extensive abdominal fibrinous lesions. A 5.0-MHz convex transducer was used. Massive echoic changes interspersed with fluid representing fibrinous peritonitis are seen between the abdominal wall and the abomasum (not visible). 1 Ventral abdominal wall, 2 Echoic lesions interspersed with fluid, 3 Fluid with gaseous inclusions (similar to those shown in Fig. 6). Cr Cranial, Cd Caudal

described in many text books [7, 29-31], although details regarding the frequency of signs are sparse. The present study examined the clinical signs associated with a perforated ulcer in detail and identified compromised health status and anorexia (100\%), abdominal guarding (81\%), congested scleral vessels (77\%), ruminal atony (73\%), tachycardia (68\%), tachypnoea (65\%), positive foreign body tests (58\%), decreased skin surface temperature (53\%) and fever $(49 \%)$ as the predominant clinical signs. However, with the exception of abdominal guarding and positive foreign body tests, these clinical signs may occur with many other disorders. Abdominal guarding and positive foreign body tests are pathognomonic for peritonitis, which is most often caused by

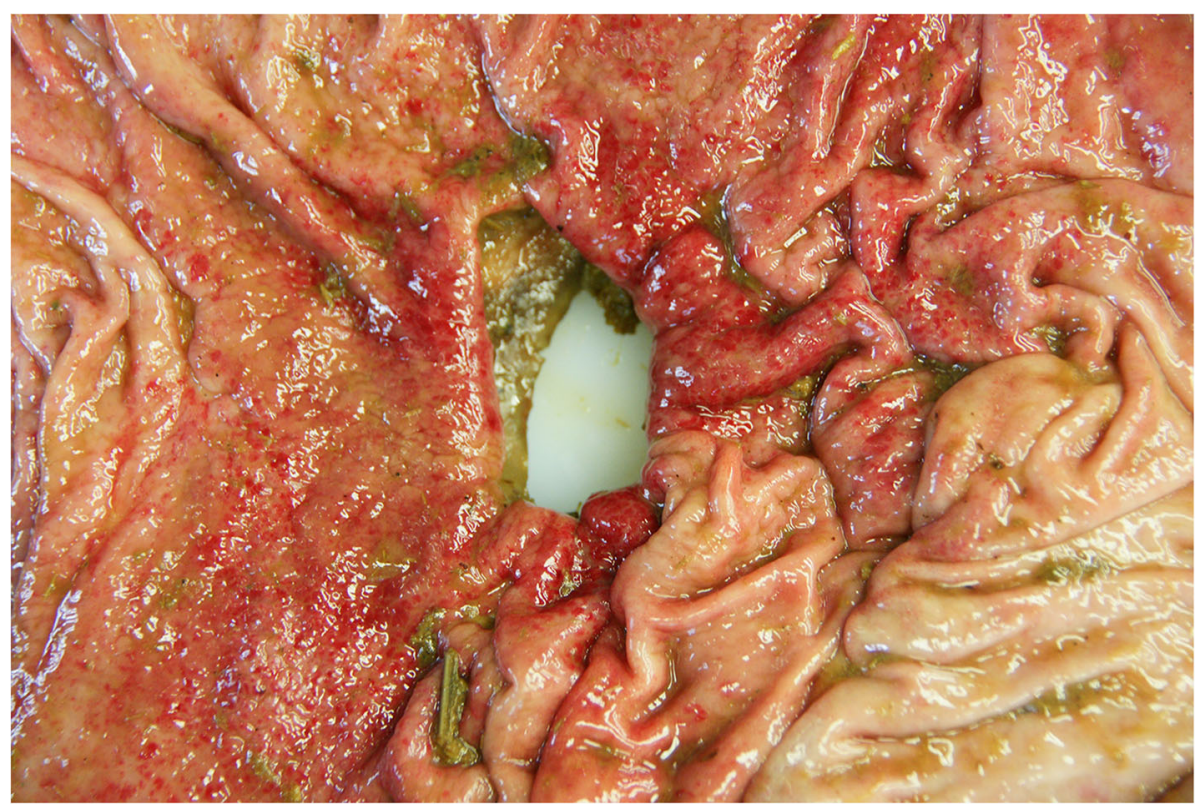

Fig. 10 Postmortem view of the luminal aspect of the abomasum with a type-4 ulcer in a 5-year-old Fleckvieh cow 


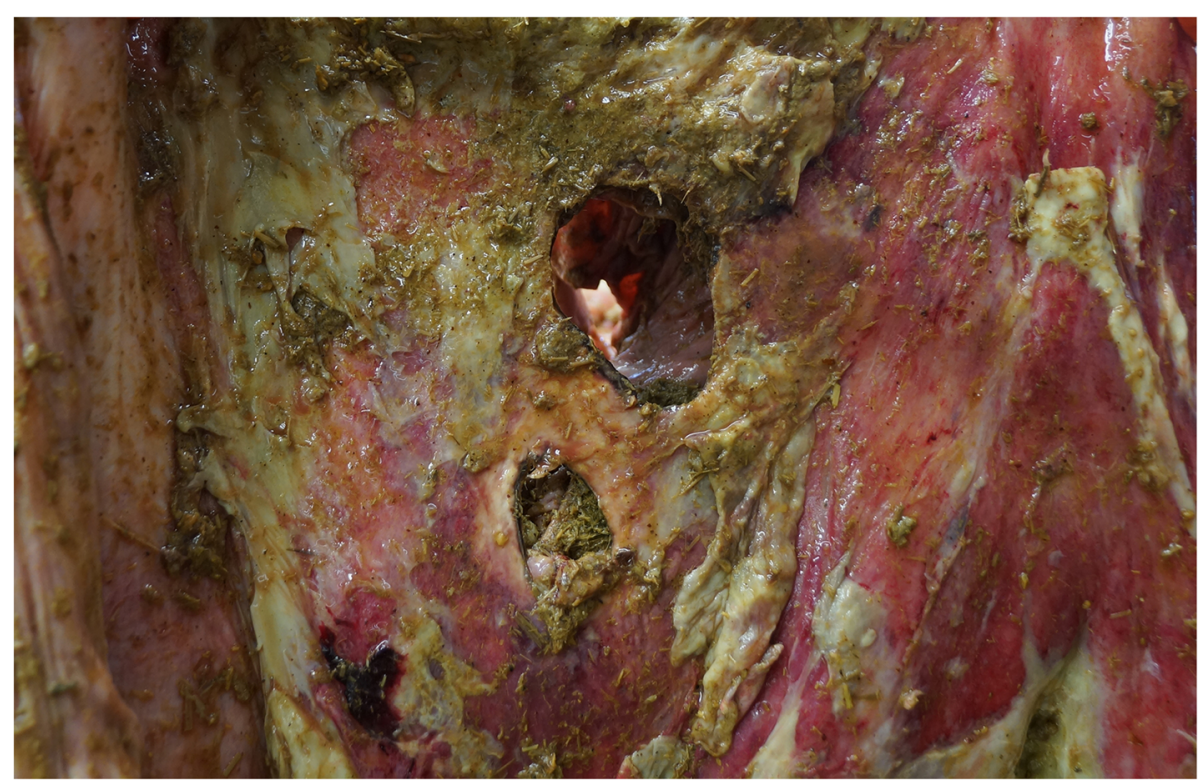

Fig. 11 Postmortem view of the serosal aspect of the abomasum with type-4 ulcers in a 7.5-year-old Fleckvieh cow. There are two perforated ulcers and the serosa is covered with ingesta and fibrin

traumatic reticuloperitonitis in cattle [32]. However, the same or similar signs of abdominal pain may also occur in disorders of the liver, omasum, lungs or, as shown here, the abomasum [32]. In the present study, 58\% of the cows had one or more positive foreign body tests; the pole test was positive in $46 \%$ and the back grip in $40 \%$. Of note, these frequencies were similar to those observed in 503 cows with traumatic reticuloperitonitis, in which the pole test was positive in $43 \%$ and the back grip in 39\% of cows [14]. Taken together, these findings show that foreign body tests are not suitable for the differentiation of type- 4 ulcer and traumatic reticuloperitonitis. Reduced or absent negative abdominal pressure detected during transrectal examination is an important clinical finding that suggests peritonitis [29] and occurred in $39 \%$ of the cows in the present study.

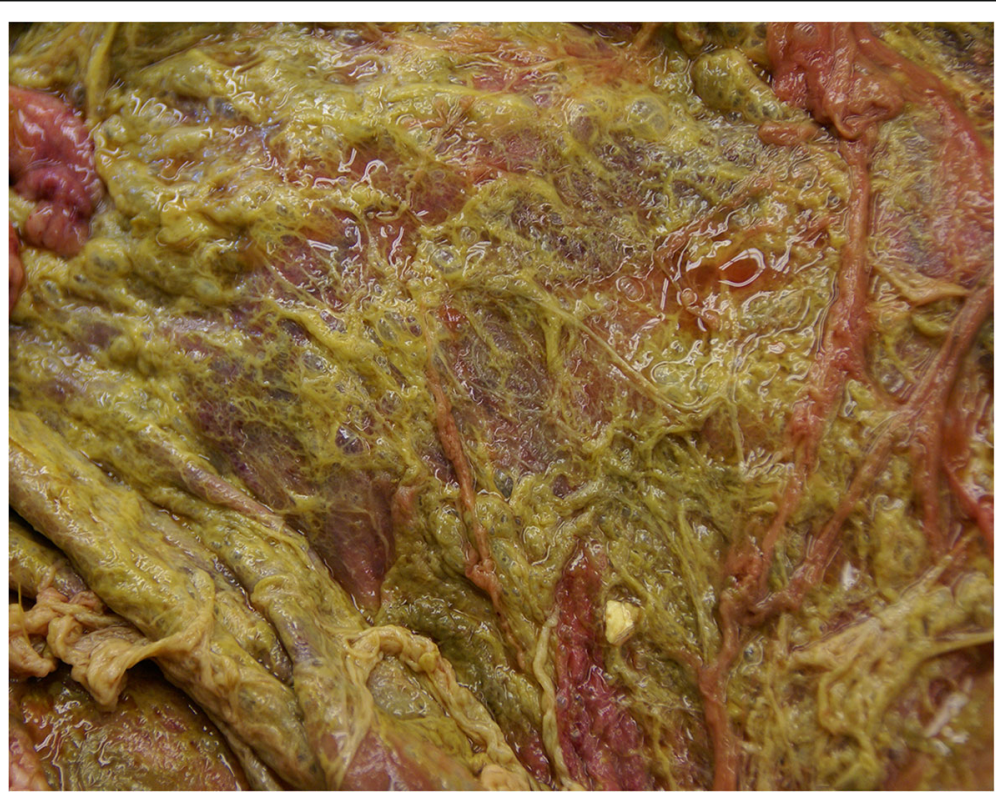

Fig. 12 Postmortem view of the greater omentum in a 2.5-year-old Fleckvieh cow with peritonitis attributable to type-4 abomasal ulcer. The greater omentum is covered with ingesta and fibrin 
Intraabdominal manoeuvrability with the examining arm is conspicuously increased compared with healthy cows [33]. Thus, type-4 abomasal ulcer is the most likely diagnosis when typical signs of peritonitis such as abdominal guarding, positive foreign body tests and fever are accompanied by a severely compromised health status, tachycardia, tachypnoea and other signs of shock. Of 503 cows with traumatic reticuloperitonitis, only $26 \%$ had tachycardia and 8\% had tachypnoea [14] compared with 68 and $65 \%$ of the cows with type- 4 ulcer. Tachycardia in cows with type-4 ulcer is attributable to shock and tachypnoea indicates pain.

Haematocrit and plasma protein are important laboratory variables in cows with type-4 ulcer. Increased haematocrit in $69 \%$ of cows indicated shock-induced haemoconcentration, but interestingly, this was accompanied by hyperproteinaemia in only $11 \%$ of cases. Usually an increase in haematocrit goes hand in hand with an increase in plasma protein concentration, but in the present study, $60 \%$ of cows had normal plasma protein concentrations and in $29 \%$ the concentration was even lower than normal. An increased haematocrit accompanied by normal or decreased plasma protein concentration is indicative of loss or active secretion of protein-rich fluid into the peritoneal cavity [34]. It constitutes an important diagnostic sign in cattle with clinical signs typical of peritonitis and reflects the enormous loss of fluid and protein into the peritoneal cavity as a result of generalised peritonitis associated with type-4 abomasal ulcer [6]. Hypoproteinaemia associated with haemoconcentration may also occur with protein-losing enteropathy. In contrast, an increased haematocrit was seen in only $12 \%$ and decreased protein concentration in only $1 \%$ of 503 cows with traumatic reticuloperitonitis [14]. Hyperfibrinogenaemia occurred in $45 \%$ of the cows in the present study. Fibrinogen is an acute-phase protein that may increase within two to three days of onset of an inflammatory disease [35]. Interestingly the glutaraldehyde coagulation test time was increased significantly (16 to $60 \mathrm{~min}$ ) in $9 \%$ of the cows. In these cows, the secretion of protein-rich fluid into the peritoneal cavity led to inadequate concentrations of inflammatory proteins in blood and thus delayed coagulation. A lack of or a severe delay in coagulation with the glutaraldehyde test in cows with clinical signs typical of peritonitis should alert the clinician to hypoproteinaemia and to the likely diagnosis of generalised peritonitis associated with effusion into the peritoneal cavity. Similar to other infectious bovine diseases, the white blood cell count was difficult to interpret in cows with type-4 ulcer. Only $19 \%$ of the cows had leukocytosis and $35 \%$ had leukopenia. By comparison, in cows with traumatic reticuloperitonitis, $42 \%$ had leukocytosis and only $4 \%$ had leukopenia [14]. Leukocyte numbers vary with species and depend on the relationship between leukopoiesis and peripheral consumption, and can vary from severely decreased to severely increased in animals with an infectious disease [36]. Leukopenia in cows with type-4 ulcer is attributable to consumption of leukocytes that exceeds the compensatory capacity of the bone marrow, which is less efficient in cattle than in other species [37]. Massive consumption of leukocytes was also seen in cattle with toxic mastitis [38]. Stress-induced secretion of corticosteroids in cows with type-4 ulcer may have contributed to leukopenia. The metabolic acidosis that was diagnosed in $49 \%$ of the cows with type-4 ulcer was likely the result of severe dehydration and anaerobic metabolism associated with shock [1]. The determination of l-lactate is useful for the characterisation of shock but unfortunately this was not done. Likewise, azotaemia in $56 \%$ of the cows was caused by shock and thus was prerenal. Aciduria was likely due to catabolic metabolism of protein as a result of chronic anorexia.

All but one of 47 peritoneal fluid samples had abnormalities typical of peritonitis including increased specific gravity and/or increased protein concentration, green discolouration suggesting contamination with ingesta or a putrid odour. However, it should be remembered that the standard classification of transudate and exudate do not always apply in sick cattle [39-42]. In contrast, the glucose concentration of peritoneal fluid has been shown to be a very sensitive and specific diagnostic parameter for septic peritonitis. The glucose concentrations of blood and peritoneal fluid are usually similar but because of glucose metabolism by microbes, the concentration is lower in peritoneal fluid than in blood in cows with septic peritonitis [43]. D-dimer concentration is considered the best criterion for the diagnosis of peritonitis [43] and is $<0.60 \mathrm{mg} / \mathrm{l}$ in healthy cattle [44]. This is a fibrin degradation product and plays an important role in the diagnosis of coagulation disorders. Peritonitis in cattle is associated with massive synthesis of fibrin immediately accompanied by fibrinolysis, which results in an increase in d-dimer concentration. It has a diagnostic sensitivity of $96 \%$ and a specificity of $98 \%$ [43]. This implies that the determination of glucose and d-dimer concentrations in peritoneal fluid should be part of the diagnostic workup in a cow suspected of suffering from peritonitis. D-dimer determination was not part of the standard examination protocol used in the present study because most cases occurred before the relationship between peritoneal d-dimer concentration and peritonitis in cattle was described [43].

Ultrasonography was useful for visualising and assessing generalised peritonitis in 47 cows. The proximity of the abomasum to the reticulum showed reticular lesions in many cows with careful scanning of both sides. This underlines the importance of a thorough examination of 
the entire abdomen even in cases where lesions that support the tentative diagnosis are readily detected. For instance, when ultrasonographic examination is limited to the reticulum in cows with a history or clinical signs typical of traumatic reticuloperitonitis, the examiner runs the risk of missing changes associated with generalised peritonitis. Widespread peritonitic changes were seen in $26 \%$ of 503 cows with traumatic reticuloperitonitis [45]. Fibrinous changes of the abomasal serosa, which provide direct evidence of a type- 4 ulcer, were seen in only seven cows; however, more extensive inflammatory lesions in the abomasal region also strongly suggest a perforated ulcer. Type- 4 abomasal ulcers have not been visualised ultrasonographically, presumably because the ulcer itself is obscured by inflammatory lesions soon after perforation. On the other hand, the resolution of 3.5 to $5.0 \mathrm{MHz}$ transducers that are routinely used may be insufficient to visualise small ulcers, and higher frequencies are associated with insufficient penetration depth of sound waves.

Cows with diffuse peritonitis attributable to a perforated abomasal ulcer respond poorly to treatment [4] and reports of successful treatment are scarce [46]. An ulcer can be resected but peritonitis is usually advanced and resistant to therapy [6]. All cows of the present study were euthanased or died peracutely; treatment was discontinued once diffuse peritonitis was confirmed.

\section{Conclusions}

The diagnosis of type- 4 abomasal ulcer based on clinical signs alone is difficult and therefore requires additional diagnostic procedures including the determination of the haematocrit and plasma protein concentration, abdominal ultrasonography and analysis of peritoneal fluid. In most cases, these steps lead to a correct diagnosis and allow timely euthanasia of the cow to prevent further suffering and unnecessary treatment costs. The dilemma faced by clinicians is that even though a correct diagnosis is usually possible, effective treatment of type- 4 abomasal ulcer is not feasible. Efforts should therefore be made to minimise or eliminate ulcerogenic factors in cattle in later pregnancy and early lactation.

\section{Abbreviations \\ EDTA: Ethylenediamintetraacetic acid; Fig.: min: Minute; $\mathrm{pH}$ : pH value; sd: Standard deviation}

\section{Acknowledgements}

The authors thank the technicians of the Medical Laboratory for the haematological and biochemical analyses and the agricultural assistants for their help with the clinical examinations.

\section{Funding}

Not applicable since it was a retrospective analysis of medical records.

\section{Availability of data and materials}

The datasets used and analysed for this study are available from the corresponding author on reasonable request.

\section{Authors' contributions}

UB initiated, planned and supervised the study and prepared the manuscript, CR analysed the medical histories of the cows as part of her dissertation, KN and CG made contributions to acquisition and interpretation of data and were involved in drafting the manuscript, $\mathrm{MH}$ was responsible for the postmortem examinations. All authors read and approved the final manuscript.

\section{Ethics approval}

This study was not submitted for ethics committee review because it is a retrospective analysis of medical records of the Clinic of Ruminants, Vetsuisse Faculty, University of Zurich. From all owners consent was obtained for taking samples of blood, urine and ruminal fluid.

Consent for publication

Not applicable.

\section{Competing interests}

The authors declare that they have no competing interests.

\section{Publisher's Note}

Springer Nature remains neutral with regard to jurisdictional claims in published maps and institutional affiliations.

\section{Author details}

${ }^{1}$ Department of Farm Animals, Vetsuisse-Faculty, University of Zurich, Winterthurerstrasse 260, CH-8057 Zurich, Switzerland. ${ }^{2}$ Institute of Veterinary Pathology, Vetsuisse-Faculty, University of Zurich, Winterthurerstrasse 260, CH-8057 Zurich, Switzerland.

Received: 1 August 2018 Accepted: 14 March 2019

Published online: 25 March 2019

\section{References}

1. Smith DF, Munson L, Erb HN. Abomasal ulcer disease in adult dairy cattle. Cornell Vet. 1983;73:213-24.

2. Ducharme NG, Desrogers A, Fubini SL, Pease AP, Mizer LA, Walker W, Trent AM, Roy JP, Rousseau M, Radcliffe RM, Steiner A. Surgery of the bovine digestive system. In: Fubini SL, Ducharme NG, editors. Farm animal surgery. Philadelphia: Saunders Elsevier; 2017. p. 223-343.

3. Whitlock RH. Bovine stomach diseases. In: Anderson NV, editor. Veterinary gastroenterology. Philadelphia: Lea and Febiger; 1980. p. 425-8.

4. Constable PD. Abomasal ulcers. In: The Merck veterinary manual, 10th. edn. New York: Merck and Co., Inc; 2010. p. 219-22

5. Fubini S, Divers TJ. Abomasal ulcers. In: Divers PJ, Peek SF, editors. Rebhun's Diseases of Dairy Cattle. Philadelphia: Saunders Elsevier; 2004. p. 167-74.

6. Palmer JE, Whitlock RH. Perforated abomasal ulcers in adult dairy cows. J Am Vet Med Assoc. 1984;184:171-4.

7. Braun U. Labmagengeschwür. In: Dirksen G, Gründer HD, Stöber M, editors. Innere Medizin und Chirurgie des Rindes. Berlin: Parey Buchverlag; 2002. p. 500-6.

8. Braun U. Labmagen. In: Braun U, editor. Atlas und Lehrbuch der Ultraschalldiagnostik beim Rind. Berlin: Parey Buchverlag; 1997. p. 69-89.

9. Braun U, Wild K, Guscetti F. Ultrasonographic examination of the abomasum of 50 cows. Vet Rec. 1997;140:93-8.

10. Braun U, Wild K, Merz M, Hertzberg H. Percutaneous ultrasound-guided abomasocentesis in cows. Vet Rec. 1997;140:599-602.

11. Braun U, Schnetzler C, Dettwiler M, Sydler T, Meyer S, Gerspach C. Ultrasonographic findings in a cow with abomasal lymphosarcoma: case report. BMC Vet Res. 2011;7:20.

12. Reif $C$. Klinische Befunde, Therapie und Krankheitsverlauf bei Kühen mit Labmagenulzera - eine Analyse von 400 Krankengeschichten, Dr Med Vet Thesis. Zurich: University of Zurich; 2016.

13. Rosenberger G. Clinical Examination of cattle. Berlin, Hamburg: Paul Parey; 1990.

14. Braun U, Warislohner S, Torgerson P, Nuss K, Gerspach C. Clinical and laboratory findings in 503 cattle with traumatic reticuloperitonitis. BMC Vet Res. 2018;14:66.

15. Braun U, Beckmann C, Gerspach C, Hässig M, Muggli E, Knubben-Schweizer G, Nuss K. Clinical findings and treatment in cattle with caecal dilatation. BMC Vet Res. 2012:8:75. 
16. Braun U. Ultrasonography of the gastrointestinal tract in cattle. Vet Clin North Am Food Anim Pract. 2009;25:567-90.

17. Braun U, Götz M, Marmier O. Ultrasonographic findings in cows with traumatic reticuloperitonitis. Vet Rec. 1993;133:416-22.

18. Braun U. Ascites in cattle: Ultrasonographic findings and diagnosis. Vet Clin North Am Food Anim Pract. 2016:32:55-83.

19. Hemmingsen I. Ulcus perforans abomasi bovis. Nord Vet Med. 1967;19:17-30.

20. Cable CS, Rebhun WC, Fubini SL, Erb HN, Ducharme NG. Concurrent abomasal displacement and perforating ulceration in cattle: 21 cases (19851996). J Am Vet Med Assoc. 1998;212:1442-5.

21. Ok M, Sen I, Turgut K, Irmak K. Plasma gastrin activity and the diagnosis of bleeding ulcers in dairy cattle. J Vet Med A Physiol Pathol Clin Med. 2001;48: 563-8.

22. Hasegawa N, Nishiwaki A, Sugawara K, Iwao I. The effects of social exchange between two groups of lactating primiparous heifers on milk production, dominance order, behavior and adrenocortical response. Appl Anim Behav Sci. 1997:51:15-27.

23. Phillips CJC, Rind MI. The effects on production and behavior of mixing uniparous and multiparous cows. J Dairy Sci. 2001;84:2424-9.

24. Shaver RD. Nutritional risk factors in the etiology of left displaced abomasum in dairy cows: a review. J Dairy Sci. 1997;80:2449-53.

25. Hund A, Wittek T. Abomasal and third compartment ulcers in ruminants and south american camelids. Vet Clin North Am Food Anim Pract. 2018;34: 35-54.

26. Hund A, Wittek T. Labmagengeschwüre beim Rind. Tierärztl Prax. 2017;45(G): $121-8$.

27. Burnett TA, Madureira AML, Silper BF, Tahmasbi A, Nadalin A, Veira DM, Cerri RLA. Relationship of concentrations of cortisol in hair with health, biomarkers in blood and reproductive status in dairy cows. J Dairy Sci. 2015; 98:4414-26.

28. Braun U, Michel N, Baumgartner MR, Hässig M, Binz TM. Cortisol concentration of regrown hair and hair from a previously unshorn area in dairy cows. Res Vet Sci. 2017;114:412-5.

29. Dirksen G. Krankheiten von Gekröse, Bauchfell und Bauchwand. In: Dirksen G, Gründer HD, Stöber M, editors. Innere Medizin und Chirurgie des Rindes. Berlin: Parey Buchverlag; 2002. p. 667-95.

30. Francoz D, Guard CL. Abomasal ulcers. In: Smith BP, editor. Large animal internal medicine. St. Louis: Elsevier Mosby; 2015. p. 815-7.

31. Constable PD, Hinchcliff KW, Done SH, Grünberg W. Abomasal ulcers of cattle. In: Constable PD, Hinchcliff KW, Done SH, Grünberg W, editors. Veterinary medicine. A textbook of the diseases of cattle, horses, sheep, pigs, and goats. St. Louis: Elsevier; 2017. p. 518-22.

32. Dirksen G. Digestive system. In: Dirksen G, Gründer HD, Grunert E, Krause D, Stöber M, editors. Clinical examination of cattle. Berlin, Hamburg: Paul Parey; 1979. p. 184-266.

33. Lorch A, Rademacher G. Klinische Untersuchung des Rindes und Differentialdiagnose praxisrelevanter Leitsymptome. Teil 6: Kuh mit beidseits vollem Abdomen infolge eines in die Bauchhöhle durchgebrochenen Labmagengeschwürs. Tierärztl Umschau. 2004;59:514-8.

34. Fecteau G, Desrochers A, Francoz D, Nichols S. Diagnostic approach to the acute abdomen. Vet Clin North Am Food Anim Pract. 2018:34:19-33.

35. Francoz D, Guard CL. Traumatic reticuloperitonitis (hardware disease, traumatic reticulitis). In: Smith BP, editor. Large animal internal medicine. St. Louis: Elsevier Mosby; 2015. p. 805-7.

36. Weiser G. Interpretation of leukocyte responses in disease. In: Thrall MA, Weiser G, Allison RW, Campbell TW, editors. Veterinary hematology and clinical chemistry. Ames: Wiley-Blackwell; 2012. p. 127-39.

37. Tornquist SJ, Rigas S. Interpretation of ruminant leukocyte responses. In: Weiss DJ, Wardrop KJ, editors. Schalm's veterinary hematology. Ames: WileyBlackwell; 2010. p. 307-13.

38. Bleul U, Sacher K, Corti S, Braun U. Clinical findings in 56 cows with toxic mastitis. Vet Rec. 2006;159:677-9.

39. Hirsch VM, Townsend HGG. Peritoneal fluid analysis in the diagnosis of abdominal disorders in cattle: a retrospective study. Can Vet J. 1982;23:348-54.

40. Wilson AD, Hirsch VM, Osborne AD. Abdominocentesis in cattle: technique and criteria for diagnosis of peritonitis. Can Vet J. 1985;26:74-80.

41. Kopcha M, Schultze AE. Peritoneal fluid. Part 1. Pathophysiology and classification of nonneoplastic effusions. Compend Contin Educ Pract Vet. 1991;13:519-25
42. Kopcha M, Schultze AE. Peritoneal fluid. Part 2. Abdominocentesis in cattle and interpretation of nonneoplastic samples. Compend Contin Educ Pract Vet. 1991;13:703-9.

43. Wittek T, Grosche A, Locher LF, Fürll M. Diagnostic accuracy of d-dimer and other peritoneal fluid analysis measurements in dairy cows with peritonitis. J Vet Intern Med. 2010;24:1211-7.

44. Wittek T, Grosche A, Locher L, Alkaassem A, Fürll M. Biochemical constituents of peritoneal fluid in cows. Vet Rec. 2010;166:15-9.

45. Braun U, Gerspach C, Warislohner S, Nuss K, Ohlerth S. Ultrasonographic and radiographic findings in 503 cattle with traumatic reticuloperitonitis. Res Vet Sci. 2018;119:154-61.

46. O'Shea T. Perforation of the abomasum and duodenum and abomasal displacement in cattle. NZ Vet J. 1976;13:15-8.
Ready to submit your research? Choose BMC and benefit from:

- fast, convenient online submission

- thorough peer review by experienced researchers in your field

- rapid publication on acceptance

- support for research data, including large and complex data types

- gold Open Access which fosters wider collaboration and increased citations

- maximum visibility for your research: over $100 \mathrm{M}$ website views per year

At BMC, research is always in progress.

Learn more biomedcentral.com/submissions 